\title{
Oppijansuomen kolligaatit ketjuuntuvissa verbirakenteissa
}

\author{
TANJA SEPPÄLÄ
}

Tiivistelmä. Tässä artikkelissa tarkastellaan suomi vieraana kielenä -oppijoiden muodostamia kolligaatteja ketjuuntuvissa verbirakenteissa. Viittaan ketjuuntuvilla verbirakenteilla finiittiverbin ja A-infinitiivin, finiittiverbin ja MA-infinitiivin sekä finiittiverbin ja deverbaalisubstantiivin yhdistelmiin (voida tehdä, mennä tekemään, aloittaa tekeminen). Tutkimuskohteena on finiittiverbin jälkeen tulevan verbin tai deverbaalisubstantiivin muoto eli verbirektiot ja verbien suuntamuotin vaatimat täydennykset. Aineisto on ICLFI-korpuksesta. Hyödynnän tutkimuksessa korpusmetodeita ja fraseologista kielentutkimusta, jonka kolligaatti-termi viittaa sananmuodon tai lemman kanssa myötäesiintyvään syntaktiseen elementtiin.

Tavoitteeni on kuvata oppijoiden ketjuuntuvia verbirakenteita ja selvittää, mitkä niistä ovat oppijoille helppoja ja mitkä vaikeita, jotta tuloksia voisi hyödyntää suomen kielen opetuksessa. Analyysissä on mukana 19 ketjuuntuvaa verbirakennetta. Aineiston suomenoppijat hallitsevat hyvin lähes kaikki A-infinitiivirektiot ja MA-infinitiivit suuntaverbien kanssa. AUTTAA- ja PYSTYÄ-rektioverbit yhdistetään natiivikielestä poikkeaviin muotoihin, mutta KÄYDÄ- ja OPPIA-verbien rektiot eivät ole erityisen vaikeita. Oppijat eivät hallitse deverbaalisubstantiivin vaativien verbien rektiota. Lisäksi lähes synonyymiset ALKAA- ja ALOITTAA-verbit sekoitetaan keskenään. Lopuksi hyödynnän vielä fraseologista näkökulmaa, kun pohdin, miten rektioiden opettamista ja oppimista voisi edistää.

Avainsanat: suomi toisena ja vieraana kielenä; rektio; verbit; fraseologinen kielentutkimus; korpustutkimus; oppijankieli; suomi 


\section{Johdanto}

Rektio tuottaa ongelmia edistyneillekin suomenoppijoille (Nissilä 2011: 197, 308), minkä vuoksi verbirektiot valikoituivat tutkimuskohteekseni. Tämä artikkeli perustuu pro gradu -tutkielmaani (Seppälä 2012). Esittelen tässä artikkelissa lyhyesti aineistoni ja fraseologista kielentutkimusta. Lisäksi tarkastelen ketjuuntuvia verbirakenteita syntaktiselta kannalta, minkä jälkeen luvussa 3 kuvaan ICLFI-korpuksen ketjuuntuvia verbirakenteita ja pyrin selittämään natiivikielestä poikkeavia esiintymiä. En vertaa aineistoani natiivisuomen korpukseen, joten tarkoitan natiivisuomella normitettua yleiskieltä. Tämä artikkeli nostaa korostetusti esille natiivikielestä poikkeavia muotoja, kun taas gradussani esittelen laajemmin myös kielenhuollon suositusten mukaisia esiintymiä. Artikkelin lopuksi pohdin, kuinka fraseologisen näkökulman voisi ottaa mukaan verbirektioiden opettamiseen.

\subsection{ICLFI-korpus ja tutkimusmenetelmä}

Käytän tutkimusaineistona Kansainvälistä oppijansuomen korpusta (International Corpus of Learner Finnish eli ICLFI), jota on koottu Oulussa vuodesta 2007 lähtien. ICLFI on sähköinen kokoelma suomea ulkomaisissa yliopistoissa opiskelevien opiskelijoiden tekstejä. ICLFIkorpuksen teksteihin on merkitty taustamuuttujat, kuten opiskelijan äidinkieli. (Jantunen 2011: 86-97.)

Äidinkieliä ICLFI-korpuksessa on 22, ja eniten tekstejä on venäjän-, viron- ja puolankielisiltä opiskelijoilta. Tekstit on jaettu opiskeluajan mukaan alkeis-, keski- ja edistyneelle tasolle. (Jantunen 2011: 88-97.) Tutkin kaikkia ICLFI-korpuksen tekstejä eli suomi vieraana kielenä -kielimuotoa yleensä, joten en tarkastele aineistoa esimerkiksi äidinkielen tai taitotason mukaan. Tutkimani korpuksen (14.2.2011) koko on noin 638000 sanetta, ja suurin osa teksteistä on edistyneiltä oppijoilta. ICLFI on korpukseksi vielä melko pieni, mikä vaikuttaa tutkimustuloksiin. 
Korpustutkimuksessa tarkastellaan kielelle tyypillisiä, toistuvia rakenteita. Jotta niitä löytyy, on tutkittava kielen elementtien frekvenssejä. Usein käytetään myös tilastollisia testejä varmistamaan, etteivät kielen elementit esiinny toistensa kanssa sattumalta. (Biber ym. 2000: 5, 8-9.) En kuitenkaan käytä tutkimuksessani tilastollisia testejä, vaan teen deskriptiivisen katsauksen oppijansuomeen frekvenssitietojen avulla.

Käytän korpuksen tutkimiseen WordSmith Tools -ohjelmaa (Scott 2006), joka etsii tutkittavan sanan tekstimassasta, antaa tietoa sanan frekvenssistä ja näyttää sanan esiintymisympäristön. Annan aineistoesimerkit konkordansseina. Konkordanssi tarkoittaa tekstirivejä, joissa näkyy hakusana ja sen ympäristö eli koteksti (Sinclair 1991: 32, 124-127).

Kun etsin korpuksesta kahden tai useamman verbin rakenteita, lähtökohtanani on finiittiverbi. Muodostan kustakin finiittiverbistä hakusanoja, jotka kattavat sen kaikki taivutusmuodot, esimerkiksi ALKAA-verbistä hakusanan $a l^{*}$. Sitten poistan manuaalisesti hakusanalla löytyneistä konkordanssiriveistä kaikki muut paitsi etsimälläni verbillä alkavat kahden tai useamman verbin tai deverbaalisubstantiivin sisältävät esiintymät.

Etsin ICLFI-korpuksesta finiittiverbien kaikkia sananmuotoja. Sanan kaikki sananmuodot sisältävää abstraktiota kutsutaan lemmaksi, jota merkitään kapiteelikirjaimilla (Sinclair 1991: 41), kuten ALKAA. Tutkimuksessani lemma sisältää myös natiivikielestä poikkeavat muodot, kuten aloivat ja oppin. Käsittelen analyysissä verbirakenteiden finiittiverbejä lemmoina, mutta koska tutkin finiittiverbien jäljessä olevien verbien ja deverbaalisubstantiivien taivuttamista, tarkastelen niiden sananmuotoja.

\subsection{Fraseologinen näkökulma kieleen}

Tarkastelen ketjuuntuvia verbirakenteita sanan (finiittiverbin) ja taivutuskategorian (A-infinitiivi, MA-infinitiivi, deverbaalisubstantiivi) myötäesiintyminä. Nykyään kontekstuaalisten myötäesiintymien tarkastelusta puhutaan fraseologisena tutkimuksena, jota on tehty useiden 
teorioiden näkökulmasta ennenkin (Gries 2008: 3-21). Fraseologinen kielentutkimus kokoaa yhteen muun muassa korpuslingvistiikan, konstruktiokieliopin, kognitiivisen kielitieteen ja psykolingvistiikan näkökulmia kielen rakenteista (Ellis 2008: 1-6).

Fraseologinen tutkimus on osoittanut, että kielillä on leksikaalisesti ja kieliopillisesti fraasimainen luonne, sillä ne omaksutaan, tallennetaan ja prosessoidaan useamman elementin rakenteina (Sinclair 1987: 320-322; Granger \& Meunier 2008: 247). Useamman elementin rakenteet eivät ole vain idiomeja, sanontoja ja fraasiverbejä, vaan myös leksikaalisia, semanttisia ja kieliopillisia myötäesiintymiä. Leksikaalisella tasolla myötäesiintymät ovat kollokaatioita, semanttisella tasolla tarkastellaan semanttista preferenssiä ja semanttista prosodiaa sekä kieliopillisella tasolla kolligaatioita. (Sinclair 1996: 80-95; Jantunen 2004: 15-29.)

Kolligaatio on sanan, lausekkeen tai sananmuodon suhde sen kotekstin tyypilliseen kielioppikategoriaan. Kolligaatti on siten kategoria, joka myötäesiintyy toistuvasti leksikaalisen elementin kanssa. Kategoria voi olla esimerkiksi sanaluokka tai jokin muu kieliopillinen piirre, kuten infinitiivi, määräinen artikkeli tai lauseasema. (Sinclair 1998: 15; Jantunen 2004: 21-24.) Esimerkiksi englannin kielessä modaaliverbit kolligoivat verbin budge (merkityksessä 'hievahtaa, saada hievahtamaan') kanssa (Sinclair 1998: 13). Suomen kielessä puolestaan aivan-adverbi saa usein verbin vasemmalle puolelleen ja adjektiivin tai adverbin oikealle puolelleen (Jantunen 2009: 367-368).

Tutkimuksessani ketjuuntuvien verbirakenteiden jälkimmäisen verbin muodon vaihtelut ovat sanan ja siihen liittyvien kieliopillisten kategorioiden kolligaatioita. Vastaavaa tutkimusta on tehnyt muun muassa Sinclair (1987: 322) set about 'ryhtyä, aloittaa' -verbistä, joka kolligoi ing-muodon kanssa (set about leaving). En tutki kaikkia mahdollisia kolligaatioita (kuten lauseasemaa), vaan keskityn jälkimmäisen verbin tai deverbaalisubstantiivin taivutusmuotoon.

Jälkimmäisten muotojen analyysissä ovat mukana deverbaalisubstantiivit, kaikki infiniittimuodot sekä virheelliset tapaukset, kuten 
persoonamuodot ja vartalot. Analyysistä on kuitenkin rajattu pois sivulausetäydennykset. En tarkastele jälkimmäisten muotojen semantiikkaa eli esimerkiksi kontekstiin sopimattomia sanoja.

\subsection{Oppijankielen fraseologia}

Granger ja Meunier (2008: 247) painottavat fraseologisen näkökulman huomioimista myös oppijankielentutkimuksessa ja kielenopetuksessa. Fraseologinen osaaminen on olennainen osatekijä kielen ymmärtämisessä sekä kielenkäytön sujuvuudessa ja tarkkuudessa, mutta kohdekieliset fraseologiset rakenteet ovat vaikeita edistyneellekin oppijalle (Granger \& Meunier 2008: 251; Ellis 2008: 7). Vaikkei oppijan tuotoksessa olisikaan kieliopillisia virheitä, epätyypilliset myötäesiintymät ja frekvenssit tuovat siihen epäluonnollisuuden tunnun (Granger 1998: 155-156; Ellis 2008: 7; Jantunen 2008: 70-71, 81-84).

Osa fraseologisista poikkeamista johtuu siitä, että oppija haluaa sanoa enemmän kuin hänen kielitaitonsa sallii tai ilmaus on voinut jäädä mieleen virheellisenä. Lisäksi rajallisen kielitaidon vuoksi oppijat ylikäyttävät fraaseja, jotka he jo osaavat. Virheisiin vaikuttavat myös muun muassa kohdekielen piirteet kuten se, onko myötäesiintymä tiukasti rajoitettu vai voiko se varioida, ja oppijan äidinkieli, sillä usein fraseologinen ilmaus käännetään sanasta sanaan äidinkielestä kohdekieleen. Oppijan on kuitenkin opeteltava ajattelemaan kuten natiivi, vaikka toisinaan äidinkielen fraseologiaa voi käyttää myös hyödyksi. (Granger 1998: 155-156, 159; Nesselhauf 2005: 239-242, 248.)

Oppijansuomen fraseologista tutkimusta ovat tehneet muun muassa Jantunen ja Brunni (2012), joiden mukaan IHMINEN- ja PITÄ̈̈-sanojen taivutusmuotojen käyttö ja kotekstuaaliset piirteet ovat erilaiset natiivisuomessa ja oppijansuomessa. Lisäksi Kalliorannan (2009) ja Jantusen (2007) suomi vieraana kielenä -tutkimuksissa PALJON-adverbillä ja KAUNIS-adjektiivilla on natiivikieleen verrattuna epätyypillisiä kollokaatioita. Grönholm (2001) on puolestaan verrannut kielikylpylasten, kaksikielisten lasten ja syntyperäisten suomenkielisten lasten kollokaatioiden 
ja idiomien oppimista. Hän huomasi muun muassa, että kaikille vaikeimpia rakenteita olivat erittäin kiinteät idiomit.

\section{Ketjuuntuvat verbirakenteet}

Poimin tutkimani rakenteet "Suomen kielioppia ulkomaalaisille" -teoksesta (White 2008), jossa esitetty näkökulma verbien yhdistämiseen on tiivistetty kuvioon 1. Verbin ja A-infinitiivin sekä verbin ja MA-infinitiivin yhdistelmät ovat verbiketjuja ja verbiketjun kaltaisia infinitiivilausekkeita (VISK $\$ 496-497)$. Joillakin verbeillä on kuitenkin syntaktisia rajoitteita, eivätkä ne yhdisty toisen verbin kanssa, vaikka semanttisesti yhdistelmä olisi mahdollinen (harrastaa *lukea). Sen sijaan siitä verbistä, joka halutaan liittää finiittiverbiin, täytyy johtaa deverbaalisubstantiivi, joka on -minen-johtimella tai muilla johtimilla muodostettu teonnnimi (ks. teonnimistä VISK $\$ 223$ ). Tätä tutkimusta varten luomani ketjuuntuva verbirakenne -käsite mahdollistaa näiden kaikkien rakenteiden käsittelemisen.

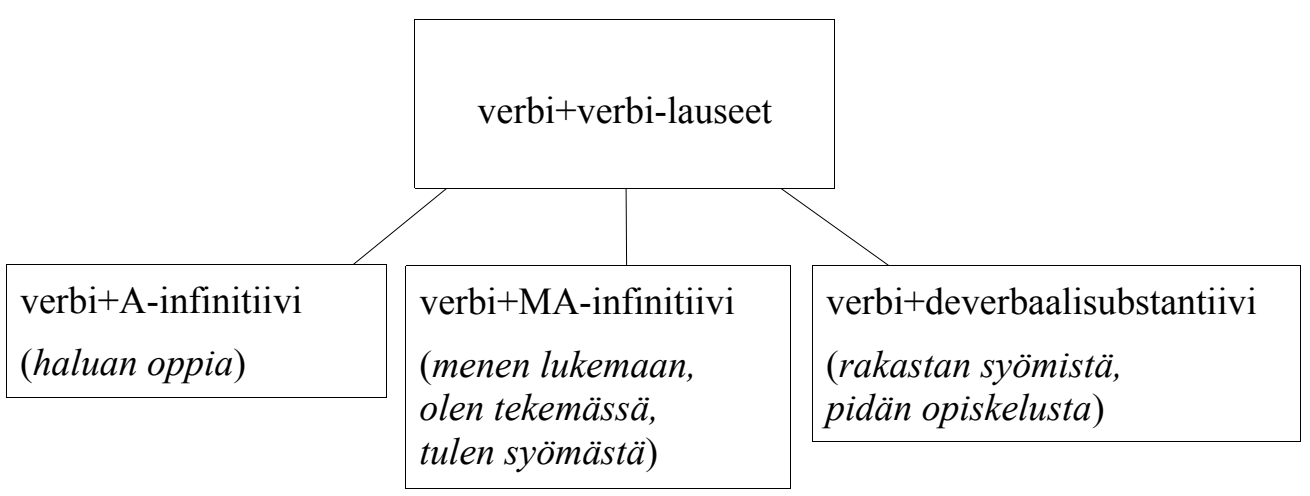

Kuvio 1. Suomenoppijoille suunnattu kielioppi (White 2008: 267-271) esittelee verbiketjut ja verbin sekä deverbaalisubstantiivin yhdistelmät osana lausetyyppejä

Ketjuuntuvien verbirakenteiden jälkimmäinen verbi tai verbikantainen substantiivi on finiittiverbin valenssin mukainen täydennys, jonka muoto riippuu finiittiverbistä. Sanan valenssi kertoo, minkä verran ja minkälaisia pakollisia seuralaisia eli täydennyksiä se saa (VISK $\$ 446-447$ ). 
Sana saattaa määrätä myös täydennyksensä sijamuodon eli rektion (VISK $₫ 448$ ). Kaikki tutkijat eivät ole kuitenkaan samaa mieltä siitä, mitkä ilmiöt kuuluvat rektioon. Joidenkin mukaan verbin rektion alaan kuuluvat muun muassa subjekti, objekti ja esimerkiksi sivulauseiden kaltaiset kompleksisemmat rakenteet (Itkonen 1997: 27-31) tai kaikkien sellaisten määritteiden rektiot, joita ilman lause olisi epätäydellinen tai epäkieliopillinen (Pajunen 1999: 6).

VISK:in ( $\$ 1225)$ mukaan silloin, kun jokin sana tarvitsee tietynsuuntaisen täydennyksen, ilmiössä ei ole kyse rektiosta, sillä sijamuotoja sanaluokkavaihtoehtoja on yleensä useita. Esimerkiksi asua-verbi saa olosijaisen täydennyksen, joka voi olla inessiivissä (Kuopiossa), adessiivissa (Rovaniemellä) tai essiivissä (rajan takana).

Rektiosijan ja semanttisesti määräytyvän sijan voi ajatella jatkumona. Rektiosijalla voi esimerkiksi olla haalistunut semanttinen yhteys. Lisäksi rektiosijan ja semanttisen sijan välillä on joukko tapauksia, joissa sija määräytyy rektionomaisesti, mutta sija kantaa kuitenkin osan yhdistelmän merkitystä. (VISK \$ 1225.)

Semanttisesti määräytyneestä sijasta on kyse esimerkiksi silloin, kun liikettä tai siirtämistä ilmaisevilla verbeillä on suuntasijainen MA-infinitiivitäydennys. Se yhdistyy myös joihinkin mentaalista tai sosiaalista tilaa ilmaiseviin verbeihin suuntautumismuotissa (opin käyttämään). Abstraktien verbien, kuten sattua ja joutua, yhteydessä on kyse rektiosta. (VISK $\$ 470,479$.)

Omassa tutkimuksessani pidän rektiona sitä, että jotkin verbit vaativat jälkeensä tulevan verbin A-infinitiiviin, MA-infinitiiviin tai deverbaalisubstantiiviin. Pääsana eli finiittiverbi määrää siis täydennyksensä eli jälkimmäisen verbin muodon ja deverbaalisubstantiivin tapauksessa myös sanaluokan. MA-infinitiivin vaativien liikeverbien kohdalla täydennyksen muodossa (mennä tekemään) on puolestaan kyse sijamuodon semanttisesta määräytymisestä.

Oppijansuomen verbirektioita ovat tutkineet muun muassa Nissilä (2011) ja Hübner (2011). Lisäksi etenkin oppijoiden syntaktisten virheiden tutkimuksissa on sivuttu verbirektioita ja deverbaalisubstantiivi- 
rektioisia verbejä. Aiemman S2-tutkimustiedon perusteella hypoteesini ovat seuraavat:

1) Suomenoppijat hallitsevat hyvin A-infinitiivin vaativien verbien rektion.

2) Suomenoppijoiden teksteissä MA-infinitiivin vaativien verbien kanssa esiintyy A-infinitiiviä.

3) Suomenoppijat yhdistävät deverbaalisubstantiivin vaativat verbit substantiivien lisäksi myös verbeihin.

\section{Ketjuuntuvat verbirakenteet oppijansuomessa}

Tässä luvussa tarkastelen suomenoppijoiden ketjuuntuvien verbirakenteiden käyttöä kokoavasti taivutuskategorioittain. Valitsin tutkimukseen ne Suomen kielioppia ulkomaalaisille -teoksen (White 2008: 267-271) ketjuuntuvat verbirakenteet (täydennettynä Kenttälän (2007: 255-257) oppikirjan yhdistelmillä), jotka ovat ICLFI-korpuksessa taivutuskategorioittain frekventeimpiä ja tarpeeksi frekventtejä. Analyysiin valikoituivat 19:1lä eri finiittiverbillä alkavat ketjuuntuvat verbirakenteet.

Vaikka luokittelen verbin tiettyyn kategoriaan (Whiten kieliopin mukaan), esimerkiksi SAADA-verbin A-infinitiivin vaativiin verbeihin, se voi saada täydennyksekseen muunlaisiakin jälkimmäisiä verbejä tai verbikantaisen substantiivin riippuen merkityksestä, jossa sitä käytetään. Siksi prosentuaalisia osuuksia esitellessäni puhun natiivikielen eli kielenhuollon suositusten mukaisista ja natiivikielen vastaisista muodoista; kumpaankin kategoriaan mahtuu monenlaisia verbikantaisia täydennyksiä ja verbitäydennyksiä. Luvun 3 esimerkkilauseet ovat ICLFI-aineistosta.

\subsection{A-infinitiivin vaativat verbit}

A-infinitiivirektioisista verbeistä tutkimukseen valikoitui viisi finiittiverbiä: VOIDA, HALUTA, SAADA, YRITTÄÄ ja ALKAA. Ketjuuntuvissa verbirakenteissa frekventeimmän finiittiverbin, vOIDA-verbin, esiintymiä on 
jopa yli 3700 ja viidenneksi frekventeimmän, YRITTÄ̈̈-verbin, lähes viisisataa. VOIDA-, HALUTA-, SAADA ja YRITTÄÄ-verbien jälkeen tulevan verbin taivutus hallitaan erittäin hyvin. ALKAA-lemman verbikolligaatit erottuvat joukosta, sillä niissä on kymmenesosa natiivikielestä poikkeavia tapauksia. Kuvio 2 esittää tulokset prosentteina. Prosenttiosuudet ovat osuuksia ICLFI-korpuksen ketjuuntuvista verbirakenteista, ei finiittiverbin kaikista esiintymistä.

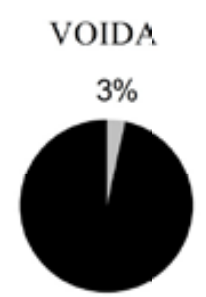

$97 \%$

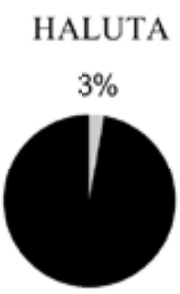

$97 \%$

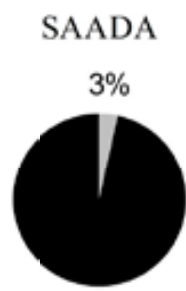

$97 \%$

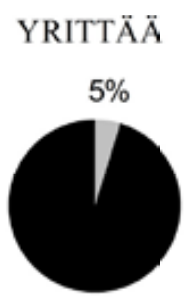

$95 \%$

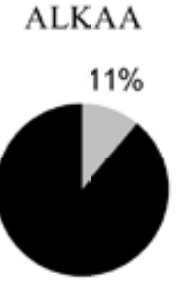

$89 \%$

Kuvio 2. A-infinitivin vaativien verbien nativikielen mukaiset (tumma väri) ja natiivikielestä poikkeavat (vaalea väri) verbikantaiset tai verbikolligaatit

VOIDA, HALUTA, SAADA, YRITTÄÄ ja ALKAA saavat valtaosassa natiivikielen mukaisia tapauksia kolligaatikseen A-infinitiivin (En voinut jopa tavata ystävät, ---. --- että saa olla kotona perheen kanssa ---.), ja ne liitetään vain muutamaan tapaa ilmaisevaan MA-infinitiivin adessiiviin ja abessiiviin sekä E-infinitiiviin. Lisäksi HALUTA-verbi saa vAn-kolligaatin (Vaikka haluan kirjeeni näyttävän hyvältä ja kunnolliselta, ---.), ja SAADA-verbin yhdistelmistä peräti $11 \%$ on saada joku tekemään jotain -rakenteita.

Kaikki viisi verbiä saavat kolligaateikseen myös natiivikielestä poikkeavia tapauksia, joista on esimerkkejä konkordanssissa 1. Yhteistä näille finiittiverbeille on, että ne saavat vartalokolligaatteja ja persoonamuotoisia kolligaatteja. Koivistonkin (1994: 97) S2-tutkimuksessa A-infinitiivin asemesta on käytetty verbin vartaloa. Toisinaan vartalo (löydä-, matkusta-) voi muistuttaa eri verbityypin A-infinitiiviä (juoda, juosta), mikä voi aiheuttaa virheen, vaikka oppija tuntisikin rektion. Myös Puro (2002: 148) pitää vartaloa epäonnistuneena yrityksenä tuottaa A-infinitiivi. Osassa vartalotapauksia (autta po. auttaa) voi olla kyse virheestä loppuvokaalin pituuden merkitsemisessä. 


\begin{tabular}{|lrcl|}
\hline \multicolumn{2}{|c|}{ vartalot ja persoonamuodot } & & \\
1 & han sinä olet? Ja miksi sinä & voit & autta lapsta? Terveisia Noora \\
2 & loon. Sisäinen juoni: Poika & haluaa & vihaa isäpulia ja haluaa pelastua äidin miehestä. P \\
3 & lkavat kymmeneeltä ja näin & saan & aamuisin ihan rauhassa touhua omia asioita. Päivä \\
4 & a ruokaa. Olin tapana myös & yrittää & menin uimahallissa ja uin. Muuten viihtyä minä h \\
5 & Hän vei sen kotiin ja tyttö & alkoi & uppoa taluun eli hän meni sinne tauluun sisälle. K \\
MA-infinitiivin illatiivi & & \\
6 & taa 2005 Suomessa ja minä & yritän & menemään Suomeen joka vuosi mutta se on kallis \\
7 & dinkielensä. Sen perusteella & alkaa & ihminen ymmärtämään kielen olemusta ja omaks \\
muut kolligaatit & & \\
8 & itkäaikainen - Vuonna 1248 & alettiin & tuomiokirkon rakentaminen - 1300- ja 1400-luvu \\
\hline
\end{tabular}

KONKORDANSSI 1. Esimerkkejä VOIDA-, HALUTA-, SAADA-, YRITTÄ̈̈- ja ALKAA-lemmojen natiivikielestä poikkeavista ketjuuntuvista verbirakenteista

Vain verbiketjun ensimmäinen verbi taipuu persoonissa, joten persoonamuototapauksissa oppijat eivät hallitse vielä verbien ketjuttamista. Myös Haapalan (2008: 67) Yleinen kielitutkinto (YKI) -aineistossa finiittisiä verbejä käytetään infiniittisten tilalta, ja Koiviston (1994: 96) tutkimuksessa etenkin alkeisoppijat yhdistävät kaksi finiittiverbiä. Passiivikolligaatit selittyvät sillä, että muutamia kertoja passiivin tunnus on yhdistetty virheellisesti jälkimmäiseen verbiin (voi ansaitaan po. voidaan ansaita).

A-infinitiivirektioisilla verbeillä on myös muutamia virheellisiä MA-infinitiivin illatiiveja. Tämä voi kertoa siitä, että oppijat tietävät joidenkin verbien vaativan MA-infinitiivitäydennyksen, mutta he eivät tiedä, mitkä verbit tarkalleen ottaen näitä ovat. Haapalan (2008: 66) YKI-aineistossakin käytetään A-infinitiivin asemesta joitain kertoja MA-infinitiiviä. Koivisto (1994: 101-102) selittää tätä ilmiötä äidinkielen interferenssillä: jos äidinkielessä ilmaus on pitkä, oppija voi luulla suomessakin tarvittavan A-infinitiiviä pidempää ilmausta. ALKAA-lemmaa lukuun ottamatta A-infinitiivirektioisilla verbeillä on kuitenkin ICLFI-aineistossa MA-infinitiivikolligaatteja vähemmän kuin vartaloita ja persoonamuotoja.

ALKAA-lemma kolligoi MA-infinitiivin illatiivin kanssa 7 \%:ssa tapauksista, mikä voi olla puhekielen vaikutusta tai taivutusvirhe. Lisäksi 
oppijat käyttävät ALKAA-verbiä hieman (3\%) deverbaalisubstantiivin kanssa. ALKAA saatetaan siis sekoittaa lähes synonyymiseen ALOITTAAverbiin.

Kaiken kaikkiaan A-infinitiiviverbien tulos vahvistaa ensimmäisen hypoteesin, jonka mukaan A-infinitiivin vaativat verbit hallitaan hyvin. Myös Nissilän (2011: 221) ja Koiviston (1994: 97) tutkimuksissa suomenoppijat hallitsevat A-infinitiivirektiot.

\subsection{MA-infinitiivin vaativat verbit}

MA-infinitiiviverbeistä analyysiin valikoitui yhteensä yhdeksän finiittiverbiä. Näistä viisi (LÄHTEÄ, MENNÄ, OPPIA, PYSTYÄ ja AUTTAA) yhdistyvät MA-infinitiivin illatiivin kanssa. MENNÄ on ICLFI-teksteissä ketjuuntuvien verbirakenteiden finiittiverbinä moninkertaisesti frekventimpi ( $f=822)$ kuin seuraavaksi frekventein AUTTAA $(f=158)$. Viidenneksi frekventein OPPIA-verbi esiintyy vain sata kertaa ketjuuntuvan verbirakenteen finiittiverbinä. Näiden viiden verbin kolligaattien hallinnassa on eroja, kuten kuviosta 3 voi huomata. Yleensä ottaen ne, etenkin AUTTAA ja PYSTYÄ, hallitaan jonkin verran huonommin kuin A-infinitiivin saavat verbit.

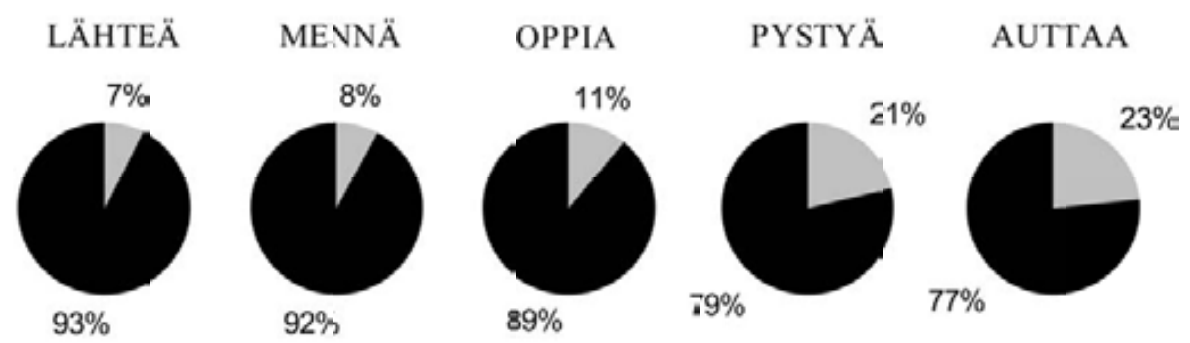

Kuvı 3. MA-infinitiivin illativin vaativien verbien natiivikielen mukaiset (tumma väri) ja natiivikielestä poikkeavat (vaalea väri) verbikantaiset ja verbikolligaatit

Valtaosa kunkin verbin kolligaateista on MA-infinitiivin illatiiveja (--- ja me lahdimme kävelemään. --- uusi kielitaito auttaa luomaan kontakteja.). Näistä muutamat ovat puhekielisessä MA-tunnuksettomassa 
muodossa (menkää kalastaan), mikä voi olla puhekielen vaikutusta tai taivutusvirhe. OPPIA saa tapaa ilmaisevia E-infinitiivi-, MA-infinitiivin adessiivi- ja abessiivitäydennyksiä (Myöhemmin kieliä opitaan opetamatta tai opetamalla.) selvästi muita verbejä enemmän (yhteensä 9\%). Muita natiivikielen mukaisia kolligaatteja ovat MENNÄ-, AUTTAA- ja OPPIA-verbien verbikantaiset substantiivit, jotka selittyvät näiden ketjuuntuvien verbirakenteiden merkityksillä ('mennä johonkin', 'auttaa jossakin asiassa' ja 'oppia jotakin').

A-infinitiivi on muilla paitsi LÄHTË̈-verbillä kaikkein frekventein natiivikielestä poikkeava yhteinen kolligaatti (konkordanssi 2). Oppijat eivät siis ehkä tunne (vielä) verbien rektiota, joten he jättävät jälkimmäisen verbin taivuttamatta tai yhdistävät verbit analogisesti voida-tyyppisten verbien mukaan A-infinitiiviin. AUTTAA yhdistetään A-infinitiiviin jopa $22 \%$ :ssa ja PYSTYÄ $21 \%$ :ssa ketjuuntuvia verbirakenteita.

\begin{tabular}{|lrcc|}
\hline A-infinitiivi & & \\
1 & tulee meille vierailu tai me & menemme & vierailla sukulaisemme. Ja tänä jouluna särkyi m \\
2 & uulen, että minä ei koskaan & opi & puhua suomea sujuvaksi. Teen paljon virheitä, va \\
3 & ntä on, että jokainen meistä & pystyisi & ainaikin kerran elämässään rehellisesti sanoa "ole \\
4 & tä. Viron kielen osaaminen & auttaa & ymmärtää paljon suomen sanoja (positiivinen tra \\
MA-infinitiivin vartalo, MAn-muoto ja MAa-muoto \\
5 & n vielä uksi luento tai sitten & lähdemme & heti kirjastoon lukeman. Kello viisi syön tavallis \\
6 & len, sekä katson televisioa. & Menen & nukkuma tavallisesti kello kaksitoista. \\
muut kolligaatit & & \\
7 & oli syntymäpäiva tulemaan & menin & valitsen torttuja. Valisin iso mansikkatorttun. Sen \\
\hline \hline
\end{tabular}

KONKORDANSSI 2. Esimerkkejä L ̈̈HTË̈-, MENN"̈-, OPPIA-, PYSTŸ̈- ja AUTTAA-lemmojen natiivikielestä poikkeavista ketjuuntuvista verbirakenteista

MA-infinitiivin illatiivin vaativilla verbeillä, etenkin LÄHTEÄ- ja MENNÄ-lemmoilla, on joitain virheellisiä MA-infinitiivikolligaatteja. MA-infinitiivin illatiivi jää esimerkiksi liian lyhyeksi, jolloin siitä tulee MA-infinitiivin vartalo, MAn- tai MAa-muoto. Oppija todennäköisesti muistaa näiden verbien vaativan täydennyksensä MA-infinitiiviin, mutta ei tiedä tai ei osaa muodostaa oikeaa sijaa. MA-infinitiivin illatiivin 
vaativat verbit eroavat A-infinitiiviverbeistä siinä, että vain MENNälemmaan yhdistetään myös persoonamuotoisia verbejä ja finiittiverbin vartaloita.

LÄHTË̈- ja MENNÄ-liikeverbien semanttisesti motivoituneet rektiot hallitaan MA-infinitiivin illatiivin saavista verbeistä parhaiten, eikä A-infinitiivi ole niillä kovin merkittävä kolligaatti, joten oppijat tuntevat liikeverbeihin liittyvän sijasysteemin. PYsTYÄ ja AUTTAA ovat semanttisesti läpinäkymättömiä rektioverbejä, ja niiden kolligaatit osataankin paljon huonommin kuin liikeverbien. Mielenkiintoista kuitenkin on, että OPPIA-verbin rektio hallitaan ketjuuntuvissa verbirakenteissa melko hyvin. Se on todennäköisesti frekventti oppijankielessä, ja sen rektioon kiinnitetään opetuksessa huomiota.

Muiden MA-infinitiivin vaativien verbien (KÄYDÄ, ISTUA, OLLA ja TULLA) hallinta on tiivistetty kuvioon 4. MA-infinitiivin inessiivin saavista verbeistä tutkimukseen valikoitui kolme finiittiverbiä. OLLA esiintyy finiittiverbinä näissä yhdistelmissä 400 kertaa, mutta kolmanneksi frekventein ISTUA vain 55 kertaa, joten yksittäisetkin esiintymät vaikuttavat paljon sen kolligaattien prosenttiosuuksiin. KÄYDÄ-, ISTUA- ja OLLA-verbien verbikantaisista tai verbitäydennyksistä noin kymmenesosa on natiivikielestä poikkeavia.
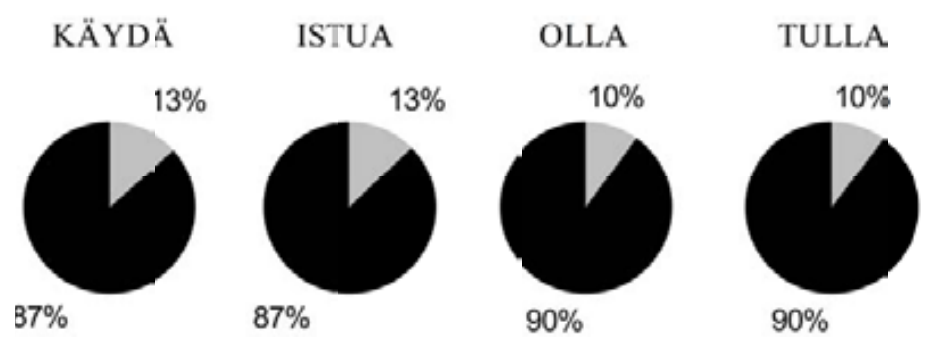

Kuvı 4. MA-infinitiivin inessiivin ja elatiivin vaativien verbien nativivielen mukaiset (tumma väri) ja nativivikielestä poikkeavat (vaalea väri) verbikantaiset ja verbikolligaatit

Frekventti olLA voi yhdistyä monenlaisiin täydennyksiin, mutta useimmiten (60\%) jälkimmäinen verbi on ICLFI-aineiston teksteissä MAinfinitiivin inessiivissä (--- Suomea ei ole enää olemassa.). Näin on myös 
KÄYDÄ- ja ISTUA-verbeillä, jotka yhdistyvät yhteensä vain kolme kertaa natiivikielen mukaisesti MA-infinitiivin illatiiviin. Koivisto (1994: 100-101) selittää MA-infinitiivin inessiivin hyvää hallintaa sillä, että olosijaiset muodot dominoivat yleensä oppijansuomessa (ks. olosijaisten muotojen yleisyydestä myös Puro 2002: 139-140).

ISTUA ja OLLA yhdistetään myös joitain kertoja E-infinitiiviin, MAinfinitiivin adessiiviin ja abessiiviin (hän oli jo uskomatta). OLLA-verbin ketjuuntuvista verbirakenteista jopa $9 \%$ on olla tekemättä -verbiliittoja. Oppijat tuntevat myös hyvin ilmiön, jossa joistain verbeistä (kuten TULLA) käytetään niiden substantiivivastinetta (tulossa) MA-infinitiivin inessiivin asemesta, sillä näitä muotoja on peräti $14 \%$ OLLA-verbin kolligaateista. Haapala (2008: 75) onkin huomannut, että suomenoppijat oppivat lyhyet olla tulossa -rakenteet jo varhaisessa vaiheessa. OLLAverbiä käytetään ICLFI-korpuksessa vain hyvin harvoin idiomimaisissa rakenteissa olla tehtävissä, olla tekemisissä ja olla tekemäisillään. KÄYD̈̈verbiin liitetään kymmenen kertaa deverbaalisubstantiivi (kävin harjoittelulla).

Natiivikielestä poikkeavista kolligaateista yhteisiä KÄYDÄ-, ISTUA- ja OLLA-verbeille ovat virheellisesti käytetyt MA-infinitiivin illatiivit (konkordanssi 3), joita OLLA-verbillä on $5 \%$, ISTUA-verbillä $7 \%$ ja KÄYDÄverbillä jopa $9 \%$ kolligaateista. KÄYDÄ saa lisäksi yksittäisiä virheellisiä MA-infinitiivejä. MA-infinitiivin inessiivin saavat verbit eroavat illatiivin saavista verbeistä siinä, että virheellisiä A-infinitiivikolligaatteja on vain hyvin vähän. Mielenkiintoista on myös, että melko frekventtiin OLLA-verbiin yhdistetään vain viisi kertaa persoonamuoto.

\begin{tabular}{|lrcr|}
\hline \multicolumn{2}{|l}{ MA-infinitiivin illatiivi } \\
1 & hmiset Puolassa tavallisesti & käyvät & hautausmaassa muistelemaan vainajat. Minä en \\
2 & 20 kuluttua...\#!:|(??!!! Me & oltiin & syömään ja sitten Lukasz keksi, että me voidaan \\
muut kolligaatit & & \\
3 & a-aika. Tässä aikassa ensin & olen & syöda lounasta ystävän kanssa ja sitten minulla o \\
\hline
\end{tabular}

KONKORDANSSI 3. Esimerkkejä KÄYDÄ-, ISTUA- ja OLLA-lemmojen natiivikielestä poikkeavista ketjuuntuvista verbirakenteista 
KÄYDÄ kuvaa edestakaista liikettä, joten sen rektiota ei voi päätellä suunnasta. Suomenoppijat eivät osaa käyttää sitä pistäytymismuotissa, vaan yhdistävät sen esimerkiksi tulosijaiseen MA-infinitiiviin (Ranua \& Ruotsalainen 2007: 54). Koiviston (1994: 103) semanttinen havainto selittää tätä: KÄYDÄ laajentuu oppijoilla usein merkitykseen 'mennä. ICLFI-korpuksessa KÄYDÄ-lemman rektiossa tehdään virheitä, mutta ei kuitenkaan enempää kuin ISTUA-verbinkään kanssa. KÄYDÄ ei siis ole aineistossani erityisen vaikea rektioverbi, tai sen rektioon on opetuksessa kiinnitetty huomiota.

MA-infinitiivin elatiivin vaativista verbeistä ainoa aineistossa tarpeeksi frekventti on TULLA, joka esiintyy vähän yli kaksisataa kertaa ketjuuntuvan verbirakenteen finiittiverbinä. Kymmenesosa TULLA-lemman kolligaateista on natiivikielestä poikkeavia (ks. kuvio 4). Monikäyttöinen TULLA liitetään useimmiten MA-infinitiivin illatiiviin, ja tämä yhdistelmä kuvaa suuntaa 80 \%:ssa (Voisitko tulla käymään Uumajassa ---?) ja tulevaisuutta 19 \%:ssa (--- edustajien, tulee tekemään vaikeaa työtä, ---.) näistä esiintymistä. Myös Haapalan (2008: 83-84) YKI-aineistossa ja Puhakan (2010: 72-92) S2-aineistossa tulee tekemään -rakenne on frekventti.

Melko usein (16 \%) TULLA saa ICLFI-teksteissä kolligaatikseen myös kontekstissaan oikein käytetyn A-infinitiivin (Teksteistä tulee käydä selville, ---.). Näitä tapauksia Haapalalla (2008: 82) on vain muutama. Oppijat yhdistävät lisäksi TULLA-verbin natiivikielen mukaisesti yhteensä seitsemän kertaa tapaa ilmaiseviin E-infinitiiviin sekä MA-infinitiivin adesssiivin ja abessiiviin. Viisi kertaa TULLA-lemmaa käytetään idiomimaisissa TULLA + TU-partisiipin partitiivi tai translatiivi -rakenteissa (tulee käytettyä, tulee toistetuksi). Yllättävää on, että TULLA kolligoi ainoastaan neljä kertaa (2 \%) MA-infinitiivin elatiivin (--- ja minä tulin hetki hiihtämästä.) kanssa.

TULLA-verbin natiivikielestä poikkeavat kolligaatit ovat lähinnä vain yksittäisiä esiintymiä. ICLFI-aineistossa TULLA saa jälkeensä joitain kertoja virheellisen A-infinitiivin (Sinulla on tulot, tulin kerätä veroa.), kuten Koiviston (1994: 112) S2-tutkimuksessakin. Suurin osa virheellisistä kolligaateista on MA-infinitiivin eri muotoja (illatiivi, vartalo, 
inessiivi, MAa- ja MAn-muoto), eli oppijat tietävät TULLA-verbin vaativan jonkin suunnan jälkeensä tulevaan verbiin. Kokonaisuudessaan TULLA-verbin kolligaattien hallinta vastaa muiden suuntaverbien (LÄHTEÄ, MENNÄ, OLLA, KÄYDÄ ja ISTUA) hallintaa.

Eräs selitys MA-infinitiiviongelmille on, että MA-infinitiivien käyttö edellyttää suomen kielen suuntasysteemin tuntemista. Vaikka oppija tietäisikin, että tietyn verbin kanssa käytetään MA-infinitiiviä, hänen on silti tehtävä vielä suuntavalinta. Lisäksi joidenkin verbien kanssa on mahdollista käyttää kahta eri suuntaisuutta (istua kuorimaan kuorimassa). (Koivisto 1994: 96-97.)

Hypoteesi kaksi eli oletus siitä, että MA-infinitiivin saavat verbit yhdistetään usein virheellisesti A-infinitiiveihin, näyttää pätevän vain ei-liikeverbien (PYstyä, AUTTAA ja OPPIA) osalta. Myös Nissilän (2011: 200-201) suomi vieraana kielenä -tutkimuksessa OPPIA ja Haapalan (2008: 66) YKI-aineistossa PYSTYÄ yhdistetään sanakirjamuotoon. Abstraktit verbit rinnastetaan siis helposti A-infinitiivin saaviin verbeihin. Toisaalta Mannisen (1997: 46) tutkimuksessa ylioppilaskokelaat käyttävät useammin MA-infinitiiviä A-infinitiivin asemasta kuin päinvastoin.

\subsection{Deverbaalisubstantiivin vaativat verbit}

Deverbaalisubstantiivin vaativista verbeistä tutkin viittä frekventeintä eli verbejä HARRASTAA, PITÄÄ, JATKAA, RAKASTAA ja ALOITTAA (PITÄ̈̈verbiä muissa kuin nesessiivisessä merkityksessä, koska rajasin nesessiiviset rakenteet pois tutkimuksestani). PIтÄÄ saa elatiivimuotoisen adverbiaalitäydennyksen, neljä muuta verbiä vaativat jälkeensä tulevan deverbaalisubstantiivin kieliopillisiin sijoihin. PITÄ̈̈-lemma esiintyy ketjuuntuvan verbirakenteen finiittiverbinä ICLFI-aineistossa yli 300 kertaa, mutta muiden verbien frekvenssit ovat 125:n (ALOITTAA) ja 45:n (RAKASTAA) väliltä, jolloin yksittäisetkin kolligaattiesiintymät vaikuttavat prosentuaalisiin osuuksiin.

Deverbaalisubstantiivin vaativien verbien verbikolligaattien ja verbikantaisten kolligaattien hallinnassa on suuria eroja, mutta pääasiassa 
oppijat osaavat näiden viiden verbin rektion huonommin kuin A- ja MA-infinitiivin vaativien verbien. HARRASTAA yhdistetään verbikantaiseen substantiiviin ehdottomasti parhaiten ja ALOITTAA selvästi huonoimmin (ks. kuvio 5).

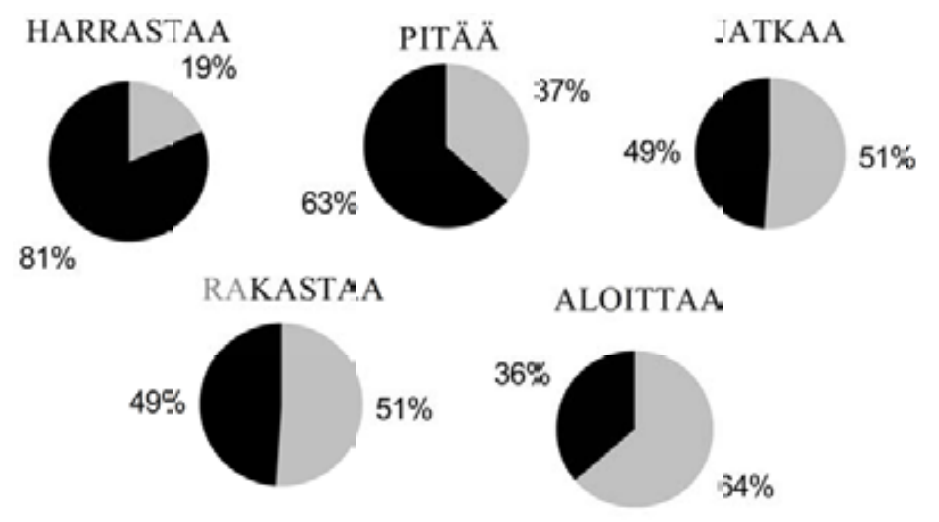

Kuvio 5. Deverbaalisubstantiivin vaativien verbien nativikielen mukaiset (tumma väri) ja natiivikielestä poikkeavat (vaalea väri) verbikantaiset ja verbikolligaatit

HARRASTAA, PITÄÄ, JATKAA, RAKASTAA ja ALOITTAA saavat kaikki deverbaalisubstantiiveja kolligaateikseen (Hän harrastaa lukemisesta ja sienestämistä. Talvella pidän luistellamisesta.). Kuviossa 5 olen laskenut kaikki verbikantaiset substantiivit natiivikielen mukaisiksi, vaikka substantiivin sija olisi natiivikielestä poikkeava. Poikkeavia sijamuotoja on substantiiveissa vain hyvin vähän. Vain PITÄ̈̈ ja JATKAA saavat muita natiivikielen mukaisia kolligaatteja, jotka ovat E-infinitiivejä.

Kaikkien viiden deverbaalisubstantiivirektioisen finiittiverbin frekventein virheellinen kolligaatti on A-infinitiivi (konkordanssi 4). ALOITTAA-verbillä A-infinitiivejä on kolligaatteina jopa enemmän (51 \%) kuin teonnimiä, ja RAKASTAA-verbilläkin A-infinitiivejä on lähes saman verran (47 \%) kuin verbikantaisia substantiiveja (49\%). 


\begin{tabular}{|lccl|}
\hline \multicolumn{2}{|l}{ A-infinitiivi } \\
1 & tossa (mutta en tiedä jota). & Harrastan & ratsastaa. Minä pidän teatterista. . \\
2 & leikkä hyvin paljon. Minä & pitänkin & lumi ja luistella ja laskea mäkeä. Minä omista \\
3 & n, että olisi mahdollisuutta & jatkaa & opiskella tätä kurssia. . \\
4 & ti ei ole, mutta äiti ja minä & rakastamme & puutarhassa työskennellä. Vastedes me varma \\
5 & että kahdessatoista maassa & aloitettiin & käyttää euroa. Toinen hyvin tärkeä asia tapaht \\
MA-infinitiivin illatiivi & & \\
6 & oko kirjoja siinä, mutta me & jatkamme & yrittämään! \\
7 & viikkoa. Sen jälkeen voisin & aloitta & nauttimaan mökkielämää. Kaikki ystäväni hal \\
muut kolligaatit & & \\
8 & Minä olen vähän ujo ja en & pidä & puhu paljon. Siksi jos ihminen puhuu minun k \\
9 & keskiyön aurinkosta. Minä & pidän & elaista Suomesta. Siellä peurat, lammat ja josk \\
\hline
\end{tabular}

KONKORDANSSI 4. Esimerkkejä HARRASTAA-, PITÄ̈̈-, JATKAA-, RAKASTAA- ja ALOITTAA-lemmojen natiivikielestä poikkeavista ketjuuntuvista verbirakenteista

A-infinitiivi on myös MA-infinitiivin vaativien abstraktien verbien tyypillinen natiivikielestä poikkeava kolligaatti. Koiviston (1994: 97) tutkimuksessa A-infinitiiviä käytetään muiden infinitiivien (sekä lauseenvastikkeiden ja partisiippien) sijaan, esimerkiksi ennen kuin MA-infinitiivi opitaan. Myös Mannisen (1997: 46) suomi toisena kielenä -aineistossa A-infinitiiviä ylikäytetään.

A-infinitiivin dominanssille on monia syitä. Se on yleensä muoto, joka oppijalle esitetään kielenoppimisen alkuvaiheessa ja joka löytyy sanakirjasta. Lisäksi useat suomen kielen finiittiverbit saavat A-infinitiivin täydennyksekseen, mikä johtaa sen liikakäyttöön. On nimittäin tyypillistä, että oppija yliyleistää kohdekielen sääntöjä (Manninen 1997: 113). Hübner (2011: 71) huomauttaakin, että oppija voi turvautua analogiaan kielitaidon ollessa puutteellinen. Lisäksi Hübner toteaa, että A-infinitiivi on lähin vastine sille verbitäydennykselle, jonka jokin verbi saa usein lähtökielessä.

HARRASTAA, PITÄÄ, JATKAA ja ALOITTAA yhdistetään virheellisesti myös MA-infinitiivin illatiiviin, JATKAA 14 \%:ssa ja ALOITTAA $13 \%$ :ssa ketjuuntuvia verbirakenteita. Oppijat voivat hahmottaa JATKAA-sanan liikettä sisältävänä suuntaverbinä, joka vaatii jälkeensä tulosijan. 
ALOITTAA-verbin MA-infinitiiviesiintymät johtuvat todennäköisesti sen sekoittamisesta lähes synonyymiseen ALKAA-lemmaan, joka saa ICLFIkorpuksessa 7 \%:ssa ketjuuntuvia verbirakenteita natiivien puhekielen tapaan MA-infinitiivin illatiivin. ALOITTAA-verbin kolligaatit osataan kuitenkin selvästi huonommin kuin ALKAA-verbin.

PITÄÄ-lemmaan yhdistetään useita persoonamuotoisia verbejä ja vartaloita, mikä voi johtua sen frekventtiydestä ketjuuntuvien verbirakenteiden finiittiverbinä. PITÄÄ saa myös kolligaatikseen MA-infinitiivin elatiiveja (leikkimästä) sekä saadasta- ja keskustelesta-muotoja (yhteensä $6 \%$ ), joissa A-infinitiiviin tai vartaloon on yhdistetty elatiivin sijapääte. Näissä tapauksissa oppija on tiennyt PITÄ̈̈-lemman vaativan täydennyksensä elatiiviin, mutta hän ei ole tuntenut deverbaalisubstantiivivaatimusta tai hän ei ole osannut muodostaa minen-substantiivia. Myös Koiviston (1994: 107-108) tutkimuksessa PIтÄÄ-lemmaan liitetään A-infinitiivin ja elatiivin (pidän lukeasta) yhdistelmiä.

Deverbaalisubstantiivin vaativat verbit ovat ICLFI-aineiston perusteella ongelmallinen verbiryhmä oppijoille, vaikkakin HARRASTAA-lemmaa osataan käyttää hieman natiivikielisemmin kuin neljää muuta verbiä. Myös muissa tutkimuksissa muun muassa TYкёTÄ-, LOPETTAA-, TARVITA-, OPISKELLA- ja OSALLISTUA-verbejä käytetään verbiketjujen finiittiverbinä (Ranua \& Ruotsalainen 2007: 36-37; Haapala 2008: 70; Paavola 2008: 36; Hübner 2011: 44, 47-48). Tätä ilmiötä voi selittää muun muassa verbien frekvenssi, sillä Koiviston (1994: 217) mukaan suomenoppijoilla on puutteita harvinaisten verbien rektioiden hallinnassa.

Hypoteesi kolme pitää paikkansa, sillä oppijat käyttävät deverbaalisubstantiivin vaativien verbien kanssa paljon verbejä, erityisesti A-infinitiivejä. Osa tuloksista johtuu varmasti kielitaitotasosta. Esimerkiksi Puron (2002) tutkimuksessa aikuiset suomenoppijat eivät olleet oppineet alkeiskurssilla, että tietyt verbit vaativat jälkeensä verbin sijaan deverbaalisubstantiivin. Sama päti RAKASTAA- ja PITÄ̈̈-verbien osalta Niirasen (2008) aineiston noin viisi vuotta suomea vieraana kielenä Norjassa oppineisiin nuoriin. Tämän vuoksi oppijat muodostavat verbiyhdistelmiä muun muassa äidinkielen mallin mukaan. (Puro 2002: 100, 
119, 125, 146; Niiranen 2008: 176-178, 301.) Kielitaidon kehittymisen myötä verbirektioiden ja verbiketjujen osaaminen kuitenkin paranee (Paavola 2008: 39; Nissilä 2011: 221).

Tutkimus herättikin monia jatkokysymyksiä. Tutkin ICLFI-korpuksen kaikkia taitotasoja ja kaikkia äidinkieliä. Jotta oppijankielen verbirektioista (ja etenkin niiden osaamisen kehittymisestä) saataisiin mahdollisimman kattava kuva, tulisi tehdä tarkempaa analyysiä, esimerkiksi taitotasoittain. Lisäksi tarkastelen ainoastaan suomi vieraana kielenä -kielimuotoa, jonka tyypilliset piirteet voivat erota suomi toisena kielenä -variantista. Aineistoni koostuu ainoastaan kirjoitetuista teksteistä, mikä voi vaikuttaa osaltaan tuloksiin.

Olisi myös mielenkiintoista verrata verbirektioita natiivikielessä sekä oppijankielessä. Tutkin ainoastaan oppijankieltä, joten en voi verrata oppijoiden kolligaatteja natiivikielen todelliseen käyttöön vaan ainoastaan kielenhuollon suosituksiin, vaikka monien verbien ( $k s$. VISK $\$ 470$ ) rektiossa natiiveillakin on vaihtelua. Olisi esimerkiksi mielenkiintoista tietää, kuinka yleinen rakastaa tehdä-rakenne on jo natiivisuomesssa.

\section{Tulosten sovellusmahdollisuuksia suomen kielen opetukseen}

Vaikka virheet ovat luonnollinen osa oppimisprosessia, usein oppijan tavoitteena on natiivin kaltainen kielitaito. Rektioiden hallinta lisää muun muassa kielenkäytön tarkkuutta. (Nissilä ym. 2006: 47, 131.) Yksi keino opettaa rektioita onkin esitellä sana ja sen rektio fraseologisena kokonaisuutena. Myös Nissilä (2011: 311) korostaa, että verbi ja sen rektio tulee opetella yhtenä konstruktiona, sillä sanaa pidemmätkin ilmaukset voivat automaattistua eli siirtyä kognition tietoisesta osasta tiedostamattomaan (Nissilä ym. 2006: 67).

Kohdekielelle altistuminen lisää vain hieman fraseologisten ilmausten osaamista, joten niitä kannattaa opettaa eksplisiittisesti luokkahuoneessa (Nesselhauf 2005: 252-254). ICLFI-aineiston perusteella MA-infinitiivin vaativien abstraktien verbien rektiot ja deverbaalisubstantiivin vaativien 
verbien rektiot ovat erityisen vaikeita, joten esimerkiksi nämä verbit ja niiden rektiot voisivat olla otollinen kohde fraseologiselle opettelulle.

Rektiot opitaan vähitellen. Tämän vuoksi oppijat kannattaa tehdä ensin tietoisiksi rektiosta ilmiönä, jotta he oppisivat havainnoimaan rektiotapauksia ja huomioimaan muun muassa yhdistymisrajoituksia. Esimerkiksi tutkimukseni perusteella suomenoppijat eivät ole (ainakaan oppimisen alkuvaiheessa) selvillä muun muassa siitä, että osa verbeistä, jotka voisivat semanttisesti yhdistyä verbeihin, ei suomen kielessä yhdistykään kuin substantiiveihin.

Oppimista voi edistää myös muun muassa rektioverbien ryhmittely (ks. esimerkiksi White 2008: 267-271), vaikka joskus sääntöjä on vaikea muodostaa (Nissilä ym. 2006: 131). Esimerkiksi semanttisesti läheiset РІтё̈̈-, түкётё- ja NAUTTIA-verbit eivät yhdisty (kirjoitetussa kielessä) verbeihin vaan ainoastaan elatiivisijaisiin substantiiveihin. Nämä verbit voisi esitellä jossain oppimisen vaiheessa yhdessä oppijoille, jotta he oivaltavat rektioverbien väliset säännönmukaisuudet. Oppijoiden tulee huomata kuitenkin myös verbien väliset erot. Siksi PITÄ̈̈-, түкÄтÄ- ja NAUTTIA-verbejä sekä niiden käyttöyhteyksiä kannattaa verrata esimerkiksi RAKASTAA-verbiin ja A-infinitiivin saaviin verbeihin.

Monimerkityksiset verbit ovat myös ongelmallisia, sillä eri merkityksissä verbi voi käyttäytyä syntaktisesti eri tavalla. Polyseemisen verbin eri merkitysten (ja eri rektioiden) esitteleminen omissa konteksteissaan voisi selkeyttää oppijoille verbin käyttöä. Samaa voisi soveltaa lähes synonyymisiin verbeihin (kuten alkaa ja aloittaa), joilla on toisistaan poikkeavat syntaktiset käyttösäännöt. Opetuksen tarpeisiin tarvittaisiin kuitenkin natiivikielen tutkimusta, jotta käyttökontekstiesimerkit voidaan tuoda mukaan opetukseen (ks. Jantunen 2009: 374-375). Toistaiseksi suomen kielestä puuttuu esimerkiksi kattava oppijoille suunnattu fraseologinen sanakirja (Järventausta 2009: 89-99).

Todennäköisesti suomen kielen opettajat esittelevätkin verbit rektioineen oppijoille ja käyttävät kontekstiesimerkkejä. Fraseologisen tietoisuuden lisääntymisen myötä fraseologinen näkökulma voisi löytää tiensä kuitenkin myös tietoiseksi opetusvälineeksi. 


\section{Tutkimusaineisto}

Kansainvälinen oppijansuomen korpus (International Corpus of Learner Finnish eli ICLFI). Koostettu hankkeessa Korpustutkimus oppijankielen kielikohtaisista ja universaaleista ominaisuuksista Oulun yliopiston suomi toisena ja vieraana kielenä -oppiaineessa. http://www.oulu.fi/suomitoisenakielena/node/16078 (20.5.2013).

\section{Lähteet}

Biber, Douglas, Susan Conrad, Randi Reppen 2000. Corpus Linguistics. Investigating Language Structure and Use. Cambridge Approaches to Linguistics. Cambridge: Cambridge University Press.

Ellis, Nick C. 2008. Phraseology. The periphery and the heart of language. - Fanny Meunier, Sylviane Granger (Eds.). Phraseology in Foreign Language Learning and Teaching. Amsterdam: John Benjamins, 1-13.

Granger, Sylviane 1998. Prefabricated patterns in advanced EFL writing: Collocations and formulae. - A. P. Cowie (Ed.). Phraseology. Theory, Analysis, and Applications. New York: Oxford University Press, 145-160.

Granger, Sylviane, Fanny Meunier 2008. Phraseology in language learning and teaching. Where to from here? - Fanny Meunier, Sylviane Granger (Eds.). Phraseology in Foreign Language Learning and Teaching. Amsterdam: John Benjamins, 247-252.

Gries, Stefan Th. 2008. Phraseology and linguistic theory: A brief survey. - Sylviane Granger, Fanny Meunier (Eds.). Phraseology: An Interdisciplinary Perspective. Amsterdam: John Benjamins, 3-25.

Grönholm, Maija 2001. Idiomien ja kollokaatioiden oppiminen suomenkielisessä kielikylvyssä. - Helena Sulkala, Leena Nissilä (Toim.). XXVII kielitieteen päivät Oulussa 19.-20.5.2000. Acta Universitas Ouluensis B 41. Oulu: Oulun yliopisto, 55-62.

Haapala, Terhi 2008. Finiittiverbeistä verbiketjuihin: verbiytimien kompleksistuminen S2-oppijoiden kielessä. Pro gradu -tutkielma. Tampere: Tampereen yliopiston kieli- ja käännöstieteiden laitos.

Hübner, Kathrin 2011. Verbirektiot kompastuskivenä: empiirinen tutkimus suomenoppijoiden rektio-termin käsittämisestä ja rektioiden hallinnasta. Pro gradu -tutkielma. Nordische Abteilung. Greifswald: Ernst-Moritz-ArndtUniversität Greifswald.

Itkonen, Esa 1997. Maailman kielten erilaisuus ja samuus. Helsinki: Gaudeamus. 
Jantunen, Jarmo Harri 2004. Synonymia ja käännössuomi. Korpusnäkökulma samamerkityksisyyden kontekstuaalisuuteen ja käännöskielen leksikaalisiin erityispiirteisiin. Joensuun yliopiston humanistisia julkaisuja 35. Joensuu: Joensuun yliopisto. http://joypub.joensuu.fi/publications/dissertations/jantunen_synonymia/jantunen.pdf (20.2.2012).

Jantunen, Jarmo Harri 2007. Oppijansuomen piirteitä korpusvetoisesti. - Pirkko Muikku-Werner, Ossi Kokko, Hannu Remes (Toim.). Virsu III. Suomalais-ugrilaisia kohdekieliä ja kontakteja. Studies in Languages 42. Joensuu: Joensuun yliopisto, 69-83.

Jantunen, Jarmo Harri 2008. Haasteita oppijansuomen korpusanalyysille: oppijankielen universaalit. - Pille Eslon (Toim.). Õppijakeele analüüs: võimalused, probleemid, vajadused. Tallinna Ülikooli eesti filoloogia osakonna toimetised 10. Tallinn: Tallinna Ülikool, 67-91.

Jantunen, Jarmo Harri 2009. "Minulla on aivan paljon rahaa" - Fraseologiset yksiköt suomen kielen opetuksessa. - Virittäjä 113 (3), 356-381. http://ojs.tsv. fi/index.php/virittaja/article/download/4202/3919 (18.6.2011).

Jantunen, Jarmo Harri 2011. Kansainvälinen oppijansuomen korpus (ICLFI): typologia, taustamuuttujat ja annotointi. - Lähivõrdlusi. Lähivertailuja 21, 86-105. http://dx.doi.org/10.5128/LV21.04

Jantunen, Jarmo Harri, Sisko Brunni 2012. Morfologinen priming ja fraseologia vieraan kielen oppimisessa: korpustutkimus oppijansuomesta. - Lähivõrdlusi. Lähivertailuja 22, 71-100. http://dx.doi.org/10.5128/LV22.03

Järventausta, Marja 2009. Kakkossuomen perussanakirja. - Virittäjä 113 (1), 89-100.

Kallioranta, Otto 2009. Paljon-adverbin kollokointi oppijansuomessa. Korpusvetoinen tutkimus. Pro gradu -tutkielma. Suomen kieli. Oulu: Oulun yliopisto.

Kenttälä, Marjukka 2007. Suomi sujuvaksi 1. Helsinki: Gaudeamus.

Koivisto, Helinä 1994. Ulkomaalaissuomen syntaksia. Tampereen yliopiston suomen kielen ja yleisen kielitieteen laitoksen julkaisuja 17. Tampere: Tampereen yliopisto.

Manninen, Terhi 1997. Vieraskielisten ongelmia ylioppilasaineessa. Pro gradu -tutkielma. Suomen ja saamen kielen ja logopedian laitos. Oulu: Oulun yliopisto.

Nesselhauf, Nadja 2005. Collocations in a Learner Corpus. Studies in Corpus Linguistics 14. Amsterdam: John Benjamins.

Niiranen, Leena 2008. Effects of learning contexts on knowledge of verbs. Lexical and inflectional knowledge of verbs among pupils learning Finnish in 
northern Norway. Väitöskirja. Department of Language and Linguistics. Tromsø: University of Tromsø.

Nissilä, Leena 2011. Viron kielen vaikutus suomen kielen verbien ja niiden rektioiden oppimiseen. Väitöskirja. Acta Universitas Ouluensis. Oulu: Oulun yliopisto. http://herkules.oulu.fi/isbn9789514296161/isbn9789514296161. pdf (25.2.2012).

Nissilä, Leena, Maisa Martin, Heidi Vaarala, Ilona Kuukka 2006. Saako olla suomea? Opas suomi toisena kielenä -opetukseen. Helsinki: Opetushallitus.

Paavola, Vilja 2008. Haluaisitko menna muunkansa kalastaman? Verbiketjujen kehkeytyminen suomi toisena kielenä -oppijoiden kielessä. Pro gradu -tutkielma. Jyväskylä: Jyväskylän yliopiston kielten laitos. https://jyx.jyu.fil dspace/handle/123456789/27247 (1.6.2012).

Pajunen, Anneli 1999. Suomen verbirektiosta. Yleisen kielitieteen julkaisuja 1. Turku: Turun yliopisto.

Puhakka, Martta 2010. "Sit se meni ja tuli hetken päästä takas": verbit mennä ja tulla suomi toisena kielenä -oppijoiden teksteissä. Pro gradu -tutkielma. Jyväskylä: Jyväskylän yliopiston kielten laitos. https://jyx.jyu.fi/dspace/ handle/123456789/24649 (20.5.2012).

Puro, Tarja 2002. Suomi toisena kielenä -aikuisoppijan verbien kehittyminen alkeiskurssilla. Lisensiaatintyö. Jyväskylä: Jyväskylän yliopiston kielten laitos.

Ranua, Minna-Mari, Margit Ruotsalainen 2007. Syntaktisten virheiden vertailua suomi toisena ja vieraana kielenä -oppijoiden teksteissä. Pro gradu -tutkielma. Suomen kielen, informaatiotutkimuksen ja logopedian laitos. Oulu: Oulun yliopisto.

Scott, Mike 2006. WordSmith Tools 4.0. Oxford: Oxford University Press.

Seppälä, Tanja 2012. Oppijansuomen kolligaatit ketjuuntuvissa verbirakenteissa. Pro gradu -tutkielma. Suomen kieli. Oulu: Oulun yliopisto. http://www. oulu.fi/sites/default/files/content/Seppala\%20gradu.pdf (1.5.2013).

Sinclair, John 1987. Collocation: a progress report. - Ross Steele, Terry Threadgold (Eds.). Language Topics: Essays in Honour of Michael Halliday. Vol. 2. Amsterdam: John Benjamins, 319-321.

Sinclair, John 1991. Corpus, Concordance, Collocation. Describing English Language. Oxford: Oxford University Press.

Sinclair, John 1996. The search for unites of meaning. - Textus IX, 75-106.

Sinclair, John 1998. The lexical item. - Edda Weigand (Ed.). Contrastive Lexical Semantics. Current Issues in Linguistic Theory 171. Amsterdam: John Benjamins, 1-24. 
VISK = Auli Hakulinen, Maria Vilkuna, Riitta Korhonen, Vesa Koivisto, Tarja Riitta Heinonen, Irja Alho 2004. Iso suomen kielioppi. Helsinki: Suomalaisen Kirjallisuuden Seura. Verkkoversio http://scripta.kotus.fi/visk (1.2.2013).

White, Leila 2008. Suomen kielioppia ulkomaalaisille. Helsinki: Finn Lectura.

\section{Tanja Seppälä}

Betonimiehenkatu 5 A 16

90530 Oulu, Finland

tanja.elisabet.seppala@gmail.com 


\title{
Colligates of learner Finnish in verb chain structures
}

\author{
TANJA SEPPÄLÄ
}

This article examines the colligates in the verb chain structures of Finnish as a foreign language. A verb chain structure is a combination of a finite verb and an A-infinitive form (alkaa tehdä 'begin to do'), a finite verb and MA-infinitive form (mennä tekemään lit. 'go to do') or a finite verb and a deverbal noun (aloittaa tekeminen 'start doing'). A colligation is a combination of a lemma or a wordform and some co-occurring syntactic element. The latter element (a verb in infinitive form or a deverbal noun) is the colligate of the finite verb.

The aim of the study is to describe the verb chain structures and the verb rections of learner Finnish and provide information that could be used in teaching Finnish as a second or foreign language. I use the International Corpus of Learner Finnish (ICLFI) as a research data and thus apply corpus methods. The theoretical frame is phraseology which emphasizes the pre-constructed nature of language.

What I found was that A-infinitive rections and MA-infinitive rections with directional verbs are easy for students. On the other hand MA-infinitive rections of more abstract verbs (auttaa 'to help', pystyä 'be able to') cause more deviation from the native Finnish. Also verbs with deverbal noun rection (for example jatkaa 'to continue' and rakastaa 'to love') are difficult and they are often used with A-infinitive. Based on the results I suggest that verbs and their rections could be taught as phraseological units and in authentic contexts.

Keywords: rection; valency; verbs; corpus methods; phraseology; learner language; Finnish 